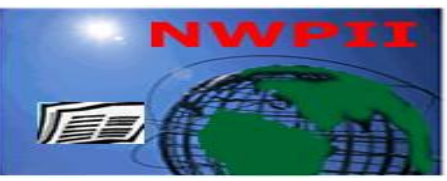

American Journal of Biomedical Sciences

ISSN: 1937-9080

nwpii.com/ajbms

\title{
Maternal Serum Level of Adiponectin and Macroscopic Changes of Placentae in Preeclampsia
}

\author{
M.A. Megahed ${ }^{1 *}$, S. M. Dawoud ${ }^{1}$, A. I. El-Sarha' ${ }^{2}$, M. A. Fayed ${ }^{1}$, and M. I. Ahmed ${ }^{3}$ \\ ${ }^{1}$ Biochemistry Department, Medical Research Institute, University of Alexandria, Egypt \\ ${ }^{2}$ Pathology Department, Medical Research Institute, University of Alexandria, Egypt \\ ${ }^{3}$ Department of gynecology and obstetrics, Faculty of Medicine, University of Benha, Egypt \\ *Corresponding Author \\ Magda A. Megahed \\ Medical Research Institute, \\ Alexandria University \\ 165, Elhorreya Avenue, Hadara, Alexandria \\ Egypt \\ Tel: $+2034282331,+2034282373$ \\ Fax: +2034283719 \\ Email: magdamegahed@hotmail.com
}

Received: 18 March 2018; | Revised:07 May 2018; | Accepted: May 302018

\begin{abstract}
The objective of the present study was to measure the serum level of adiponectin in preeclamptic Egyptian pregnant women and find the possible correlations of maternal adiponectin level to measured insulin resistance in such case and to macroscopic features of placentae included in this study.

The study population consisted of 30 preeclamptic patients and 30 matched healthy pregnant women during the third trimester.

The results revealed that preeclamptic women were more insulin resistant with a significant decrease in adiponectin level compared with healthy controls. Correlation analysis presented a significant negative correlation between adiponectin levels and measured insulin resistance among preeclamptic women. Pregnant women with preeclampsia had lower placental weight and decreased number of cotyledons with marginal insertion of umbilical cord. The present study did not show any correlations between adiponectin levels versus macroscopic features of placentae among preeclamptic mothers.

It can be concluded that preeclamptic mothers are more insulin resistant, which was reflected through increased HOMA-IR value; this relationship postulates that insulin resistance may be one of the casual pathways of preeclampsia. Hypoadiponectinemia may be one of the possible etiologies of preeclampsia. Preeclamptic placentae exhibited definite morphological changes which may be attributed to the vascular insufficiency of placenta.
\end{abstract}

Keywords: Adiponectin, Preeclampsia, Insulin resistance, Placenta 


\section{Background}

Preeclampsia (PE) is a multi-system disorder of pregnancy, which is characterized by new onset hypertension (systolic and diastolic blood pressure of $\geqslant 140$ and $90 \mathrm{~mm} \mathrm{Hg}$, respectively, on two occasions, at least 6 hours apart) and proteinuria (protein excretion of $\geqslant 300 \mathrm{mg}$ in a $24 \mathrm{~h}$ urine collection, or a dipstick of $\geqslant 2+$ ), that develop after 20 weeks of gestation in previously normotensive women ${ }^{[1]}$.

Insulin Resistance (IR) syndrome is comprised of a cluster of metabolic abnormalities that confer increased risk of diabetes, hypertension and cardiovascular disease ${ }^{[2]}$. Several features of the insulin resistance syndrome, such as obesity, hypertension, dyslipidemia, systemic inflammation and impaired fibrinolysis, are also associated with preeclampsia. In addition, women with polycystic ovary syndrome or gestational diabetes, two disorders characterized by insulin resistance, are at increased risk of preeclampsia. Collectively, these data suggest that insulin resistance may contribute to the pathogenesis of preeclampsia ${ }^{[3]}$.

Adipose tissue represents an active endocrine organ that releases a large number of bioactive mediators (adipokines) that signal to organs of metabolic importance including brain, liver, skeletal muscles and the immune system thereby modulating hemostasis, blood pressure, lipid and glucose metabolism and inflammation. These adipokines include adiponectin, leptin and others ${ }^{[4]}$.

Adiponectin is an abundant protein hormone which belongs to a family of so-called adipokines. Adiponectin is expressed mostly by adipocytes and is important regulator of lipid and glucose metabolism. It is established that adiponectin is an insulin-sensitizing hormone with anti-diabetic, antiinflammatory and anti-atherogenic properties ${ }^{[5]}$.

Plasma levels of adiponectin, which is derived mainly from adipose tissue and possibly from placenta, is inversely correlated with insulin resistance and is consequently reduced in obesity and Type 2 diabetes, but it is paradoxically irregular in preeclampsia ${ }^{[6-8]}$.

The aim of this present study was to measure the plasma levels of adiponectin in normotensive and preeclamptic Egyptian pregnant women and the possible correlations of adiponectin levels to the measured insulin resistance in such cases and to the macroscopic features of the placentae included in this study.

\section{Patients and Methods}

\subsection{Patients}

This study was conducted in the departments of Obstetrics and Gynecology in Benha, Mansoura Universities Hospitals and Biochemistry Department Medical Research Institute, Alexandria University. It included sixty pregnant women, recruited from the attendants of the outpatient clinic of Obstetrics Gynecology Department during their third trimester of pregnancy. A written and verbal consent has been obtained from all participants in the study according to the Instructions and Guidelines of the Ethics Committee of the Medical Research Institute, Alexandria University. They were divided into two groups: -

Group I: Consists of thirty pregnant women with no obstetric or medical complications of pregnancy, no medications were given during pregnancy apart from tonics and iron.

Group II: Consists of thirty preeclamptic women with blood pressure $140 \mathrm{mmHg}$ or higher systolic or $90 \mathrm{mmHg}$ diastolic after 20 weeks of gestation in women with previously normal blood pressure and proteinuria +1 or greater on urine dipstick test.

Exclusion criteria were patients with combined chronic diseases e.g., diabetes mellitus, autoimmune disease, thyroid, heart, chest, kidney, liver diseases and patients with preexisting chronic hypertension or taking hormonal therapy.

\subsection{Methods}

All subjects included in this study were asked for complete history and subjected to clinical and obstetrical examination. During fasting condition, urine and blood samples were collected from each case. $5 \mathrm{~mL}$ blood from each case was taken and allowed to clot for 30 minutes before centrifugation for 15 minutes at $1000 \mathrm{x}$ g. Serum collected and stored in three aliquots at $-20^{\circ} \mathrm{C}$.

Biochemical studies:

1-Creatinine levels [9]: Quantitative determination of urinary creatinine was performed 
according to the manufacturer's instructions (Diamond Diagnostics) with detection limit 0.09 $\mathrm{mg} / \mathrm{dL}$.

2-Albumin levels ${ }^{[10]}$ : Quantitative determination of urinary albumin was measured turbidimetry as to manufacturer's instructions (Biosystems S.A. Costa Brava 30, Barcelona, Spain).

Calculation of urinary albumin creatinine ratio (UACR): Usually expressed as milligram of albumin excreted per gram of urinary creatinine ${ }^{[11]}$.

3-Fasting glucose levels ${ }^{[12]}$ : It was measured using enzymatic colorimetric glucose oxidase method (kit purchased from spin react, Spain) with detection limit from $1 \mathrm{mg} / \mathrm{dL}$ to linearity limit 500 $\mathrm{g} / \mathrm{dL}$.

4-Insulin levels [13]: Concentration of insulin was measured using ELISA method according to the manufacturer's instructions (DRG International Inc., USA, (EIA-2935)).

Calculation of Insulin resistance: It was calculated by using homeostasis model assessment of insulin resistance (HOMA-IR) ${ }^{[14]}$.

HOMA-IR=fasting insulin $(\mu \mathrm{IU} / \mathrm{mL}) \times$ fasting glucose $(\mathrm{mmoh}) / 22.5$

4- Adiponectin levels ${ }^{[15]}$ : Adiponectin levels were measured using ELISA method according to the manufacturer' $\mathrm{s}$ instructions (RayBiotech Inc, USA, Cat\#: ELI-ADIPONECTIN-001).
Pathological studies:

The placentae were collected after delivery. The shape, weight, number of cotyledons, and site of insertion of umbilical cord of placentae was noted.

Statistical analysis:

Quantitative variables were expressed as the mean, standard deviation and range and analyzed using unpaired t-test in parametric data (SD (standard deviation) $<50 \%$ mean) where Mann Whitney Willcoxon $U$ test was used instead of unpaired t-test in non-parametric data ( $\mathrm{SD}>50 \%$ mean). Qualitative variables were expressed as number and percentage and analyzed using Chisquare test. Fisher exact test was used instead of chi-square when one or more expected cell $\leqslant 5$ and all hypothesis tests were two-tailed with statistical significance assessed at the $\mathrm{p}$-value $\leqslant 0.05$.

\section{Results}

The present study results showing a significant decrease in gestational age at delivery in preeclamptic group than control group, in addition to a significant increase in body mass index, systolic blood pressure and diastolic blood pressure in preeclamptic group than control group but results did not show any significant difference between preeclamptic and control groups in maternal age and parity (Table 1).

Table 1: Clinical characteristics in control and preeclamptic groups

\begin{tabular}{|c|c|c|c|}
\hline variables & Controls $(n=30)$ & Preeclamptic group $(\mathrm{n}=30)$ & p-value \\
\hline $\begin{array}{c}\text { Age (years) } \\
\text { Range } \\
\text { Mean } \pm \text { SD }\end{array}$ & $\begin{array}{c}22-36 \\
27.27 \pm 3.57\end{array}$ & $\begin{array}{c}20-35 \\
27.50 \pm 3.09\end{array}$ & $\mathrm{P}=0.787$ \\
\hline $\begin{array}{c}\text { Gestational age at delivery (weeks) } \\
\text { Range } \\
\text { Mean } \pm \text { SD }\end{array}$ & $\begin{array}{c}37-41 \\
38.80 \pm 1 \\
\end{array}$ & $\begin{array}{c}34-39 \\
37.07 \pm 1.26 \\
\end{array}$ & $\mathrm{P}<0.0001^{*}$ \\
\hline $\begin{array}{c}\text { Parity } \\
\text { Primiparous } \\
\text { Multiparous } \\
\end{array}$ & $\begin{array}{l}11(36.66 \%) \\
19(63.33 \%)\end{array}$ & $\begin{array}{l}17(56.67 \%) \\
13(43.33 \%)\end{array}$ & $\mathrm{P}=0.121$ \\
\hline $\begin{array}{c}\text { Body mass index }(\mathrm{kg} / \mathrm{m} 2) \\
\text { Range } \\
\text { Mean } \pm \text { SD }\end{array}$ & $\begin{array}{c}22.6-33 \\
26.38 \pm 1.99\end{array}$ & $\begin{array}{c}24.6-34 \\
28.70 \pm 2.29\end{array}$ & $\mathrm{P}<0.0001^{*}$ \\
\hline $\begin{array}{c}\text { Systolic blood pressure }(\mathrm{mmHg}) \\
\text { Range } \\
\text { Mean } \pm \text { SD }\end{array}$ & $\begin{array}{c}90-130 \\
113.33 \pm 9.94\end{array}$ & $\begin{array}{c}140-210 \\
162.33 \pm 18.79\end{array}$ & $\mathrm{P}<0.0001^{*}$ \\
\hline $\begin{array}{c}\text { Diastolic blood pressure }(\mathrm{mmHg}) \\
\text { Range } \\
\text { Mean } \pm \text { SD }\end{array}$ & $\begin{array}{c}60-85 \\
76.17 \pm 5.68\end{array}$ & $\begin{array}{c}90-120 \\
103.33 \pm 10.61\end{array}$ & $\mathrm{P}<0.0001^{*}$ \\
\hline
\end{tabular}

*: Statistically significant at $\mathrm{p} \leq 05$. 
The present study results show also a significant increase in urinary albumin creatinine ratio and insulin resistance value in preeclamptic mothers than healthy controls in addition to a significant decrease in adiponectin levels in pregnant women with preeclampsia compared with healthy controls (Table 2).

Table 2: Biochemical measurements in control and preeclamptic groups

\begin{tabular}{|c|c|c|c|}
\hline variables & Controls $(\mathrm{n}=30)$ & Preeclamptic group $(\mathrm{n}=30)$ & $\mathrm{p}$-value \\
\hline Albumin creatinine ratio (mg/g) & $\begin{array}{c}6.9-62.1 \\
\text { Range }\end{array}$ & $\begin{array}{c}157.3-398.9 \\
302.30 \pm 67.59\end{array}$ & $\mathrm{P}<0.0001^{*}$ \\
Mean \pm SD & $22.47 \pm 12.52$ & $1.22-4.07$ & \\
\hline HOMA-IR & $0.97-3.82$ & $3.23 \pm 0.72$ & $\mathrm{P}<0.0001^{*}$ \\
Range & $2.06 \pm 0.68$ & $119.4-789.1$ & $\mathrm{P}=0.003^{*}$ \\
Mean \pm SD & $212.5-991.7$ & $489.82 \pm 155.1$ & \\
\hline Adiponectin (pg/ml) & $620.6 \pm 176.4$ & & \\
Reange \pm SD & & & \\
\hline
\end{tabular}

*: Statistically significant at $\mathrm{p} \leq 0.05$

Results showed that preeclamptic mothers had lower placental weight and decreased number of cotyledons with marginal insertion of cord compared with control group but results did not show any difference between preeclamptic and control groups in placental shape (Table 3, Fig 1).

Table 3: Macroscopic examination of placenta in control and preeclamptic groups

\begin{tabular}{|c|c|c|c|}
\hline variables & Control group $(\mathrm{n}=30)$ & Preeclamptic group $(\mathrm{n}=30)$ & $\mathrm{p}$-value \\
\hline Placental Shape & $16(53.33 \%)$ & $13(43.33 \%)$ & \\
Circular & $\begin{array}{c}(13.33 \%) \\
\text { Irregular } \\
\text { Oval }\end{array}$ & $\begin{array}{c}6(20 \%) \\
11(36.66 \%)\end{array}$ & $\mathrm{P}=0.685$ \\
Yes & $10(33.33 \%)$ & $8(26.67 \%)$ & $\mathrm{P}=0.026^{*}$ \\
No & $29(96.67 \%)$ & $22(73.33 \%)$ & \\
\hline Marginal insertion of cord & $391-612$ & $328-512$ & $\mathrm{P}<0.0001^{*}$ \\
Range & $500.53 \pm 46.28$ & $413.80 \pm 47.94$ & \\
Mean \pm SD & $17-23$ & $14-22$ & $\mathrm{P}=0.002^{*}$ \\
Pacental weight (grams) & $19 \pm 1.53$ & $17.63 \pm 1.77$ & \\
\hline Meange \pm SD & & &
\end{tabular}

*: Statistically significant at $\mathrm{p} \leq 0.05$

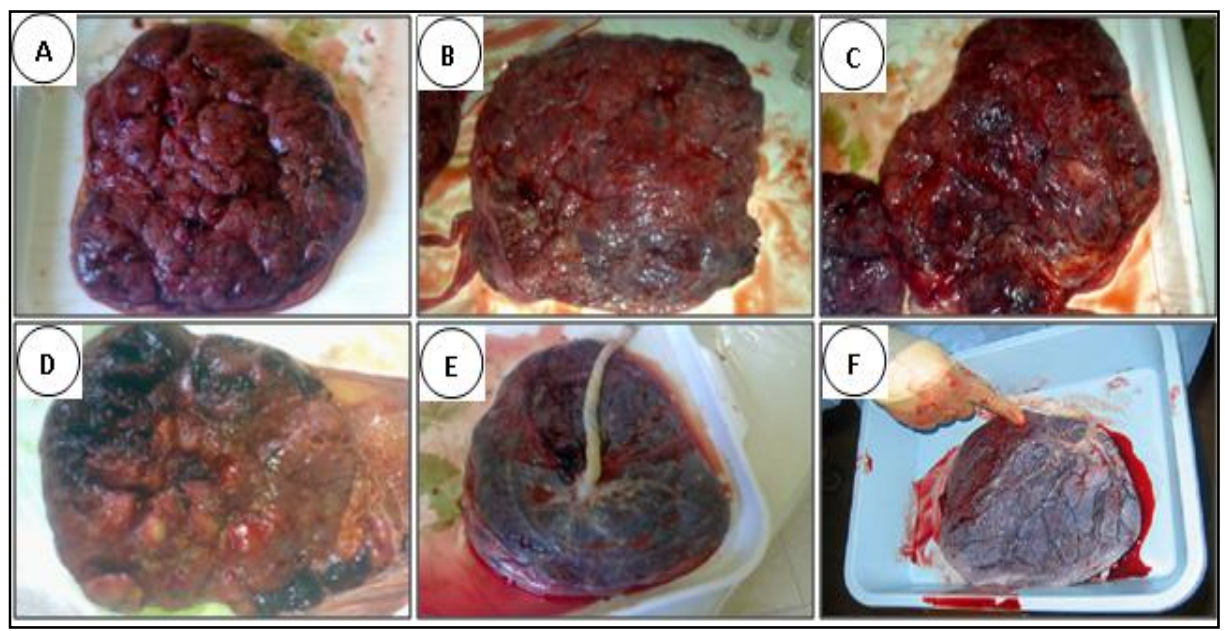

Figure 1: Different shapes of placentae and insertion of the cord: A (Normal), B, C, D (shapes of preeclamptic placentae), $\mathbf{E}$ (normal insertion of cord) and $\mathbf{F}$ (marginal insertion of cord).

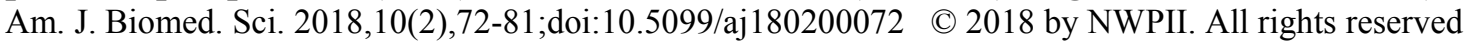


Correlation analysis found that there was a significant negative correlation between maternal serum levels of adiponectin versus body mass index $(\mathrm{r}=-0.456, \mathrm{p}=0.011)$, systolic blood pressure $(\mathrm{r}=$ $0.425, \mathrm{p}=0.019)$, diastolic blood pressure $(\mathrm{r}=$ -
$0.514, p=0.004)$ and insulin resistance value $(r=$ 0.397, $\mathrm{p}=0.030$ ) (Fig 2), but study results did not find any correlations between adiponectin levels versus macroscopic features of placentae among preeclamptic mothers.
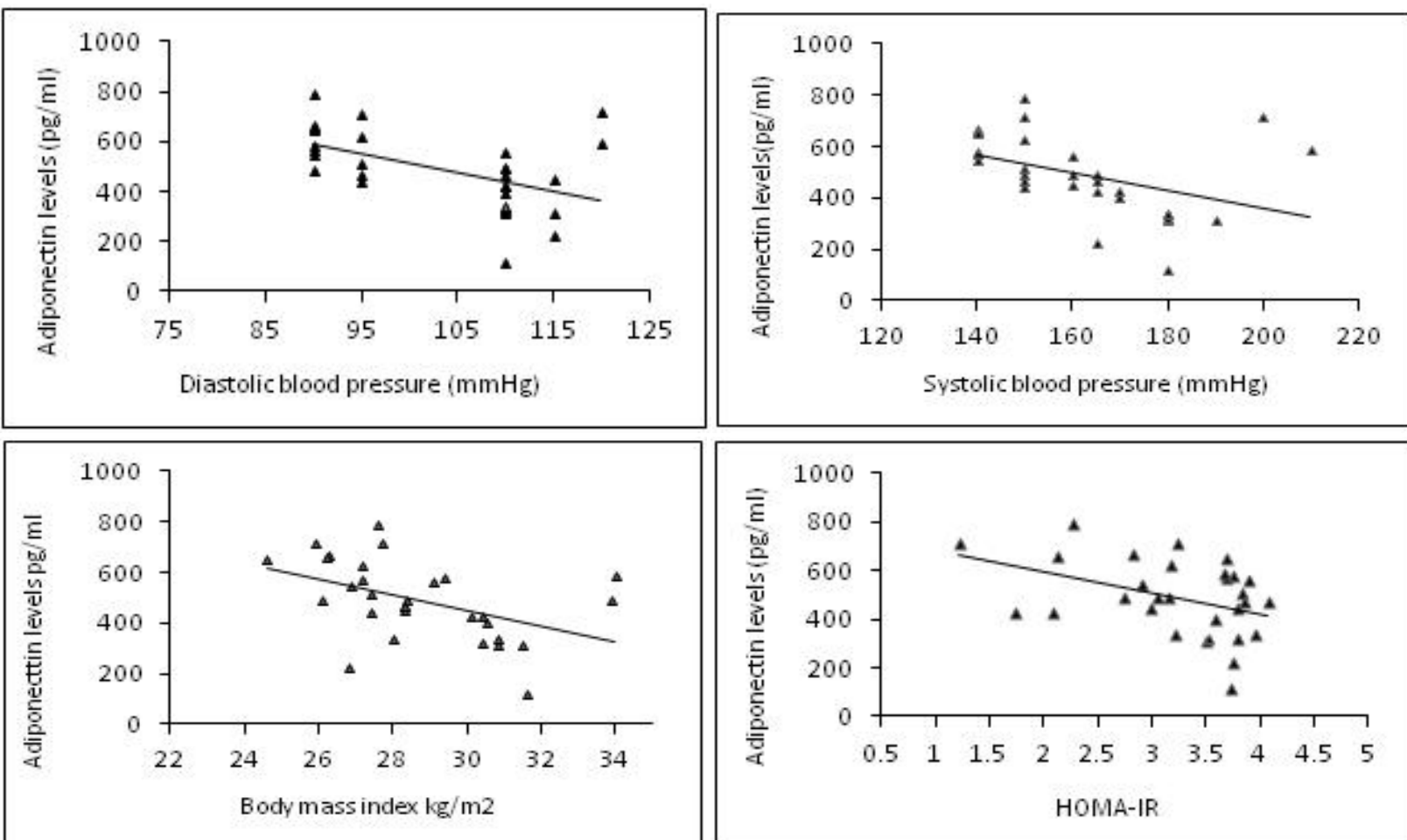

Figure 2: Correlation between adiponectin level versus body mass index, systolic blood pressure, diastolic blood pressure and HOMA-IR among preeclamptic women

\section{Discussion}

Zhang H. and Zhang C. ${ }^{[16]}$ in their review stated that the general concept has emerged that chronic low-grade inflammation is the condition linking excessive development of adipose tissue and obesity-associated pathologies such as type 2 diabetes and cardiovascular diseases. Obesity and type 2 diabetes are characterized by a diminished production of protective factors such as adiponectin and increased detrimental adipocytokines such as leptin, resistin, interleukin-6 (IL-6), tumor necrosis factor-alpha (TNF), and monocyte chemoattractant protein-1 (MCP-1) by adipose tissue. Moreover, the evidence that the growth of the fat mass is associated with an accumulation of adipose tissue macrophages and T-lymphocytes has raised the hypothesis that the development of an inflammatory process within the growing fat mass is a primary

Am. J. Biomed. Sci. 2018,10(2),72-81;doi:10.5099/aj180200072 event involved in the genesis of systemic metabolic and vascular alterations ${ }^{[16]}$

Insulin resistance in pregnancy and pregnancy complications is mainly attributed to placental hormones ${ }^{[17]}$. Many investigations have focused on several potential mediators of insulin resistance, including adipose tissue derived hormones, adipocytokines. During pregnancy adipocytokines are also secreted by placenta ${ }^{[18-20]}$. In the present study we confirmed the existence of important changes in some adipocytokines, namely; adiponectin in pregnant women with preeclampsia compared with healthy pregnant women. The present study found a significant increase of insulin resistance value in preeclamptic group than control group. These results partially in agreement with those of Masuyama et al. ${ }^{[21]}$ who found HOMA-IR in overweight patients with late-onset preeclampsia was significantly high. Placental oxidative stress is regarded as an intermediate event in the (C) 2018 by NWPII. All rights reserved 
pathogenesis of preeclampsia ${ }^{[22]}$. Several studies have addressed the molecular mechanisms by which oxidative stress might lead to insulin resistance. In vitro, Reactive oxygen species (ROS) and oxidative stress lead to activation of multiple serine/threonine kinases signaling cascades, these activated kinases can act on a number of potential targets in the insulin signaling pathway ${ }^{[23]}$.

Adiponectin is the most abundant adipose tissue specific protein ${ }^{[24]}$ Adiponectin receptors are abundantly expressed in human placenta [25], whereas, adiponectin expression by placenta during pregnancy is detectable ${ }^{[25,26]}$. Our results showed a significant decrease in adiponectin levels in preeclamptic women than normal pregnant women and these results were in agreement with that reported by Khosrowbeygi et al ${ }^{[27]}$ and Mori et al ${ }^{[8]}$. Masuyama et al ${ }^{[28]}$ did not support these results; they found a significant increase in adiponectin level in late-onset preeclamptic group. Hemoconcentration is a main characteristic of preeclampsia. However, it was shown that significant difference in levels of adipocytokines between preeclamptic and normal pregnant women is not affected by correcting adipocytokines levels for hematocrit ${ }^{[29]}$. Hyperleptinemia might contribute to the decreased levels of adiponectin and this assumption were in a line with results of Khosrowbeygi et al. ${ }^{[27]}$. They found a significant negative correlation between leptin and adiponectin that might confirm our hypothesis. As well D'Anna et al. [30] also reported that there was a strong association between hypoadiponectinemia and preeclampsia and that plasma adiponectin could be predictive of pregnancy induced hypertensive disorders. Unlike our results, Ramsay et al. [7] suggested that elevation of plasma adiponectin may be result of compensatory mechanism for decreased expression of adiponectin receptors in muscles and adipose tissue or due to an exaggerated adipocyte release or a physiological response to increased use of fat. However, he believed that possibility of a clear renal dysfunction in preeclampsia lead to increase circulating adiponectin could not be excluded, although no correlation between adiponectin and urine protein or urate was found by Lu et al. ${ }^{[31]}$.

Concerning macroscopic examination of placentae, there was no statistically significant difference in placental shape between preeclamptic and control groups but it was found a significant decrease in cotyledon numbers per placenta in preeclamptic group than control group and these results were in agreement with those of Kishwara et al. ${ }^{[32]}$. The present study results demonstrated that preeclamptic group had a significant increase in marginal insertion of the cord with a significant decrease in placental weight compared with control group and these findings were in agreement with those of Majumdar et al. ${ }^{[33]}$ Vasospasm, apoptosis and compensatory hyperplasia causing loss and fibrosis of parenchymal tissue results in lowered weight, diameter and central thickness of placentae in hypertensive pregnant women ${ }^{[34]}$.

Correlation analysis presented a significant negative correlation between maternal serum adiponectin levels with both systolic and diastolic blood pressure in preeclamptic group and these finding was in line with that of Abd-Alaleem et al. ${ }^{[35]}$. Moreover, Ouchi et al. ${ }^{[36]}$ concluded that this effect may be mediated via inflammatory pathway or lipid metabolism. Moreover, hypoadiponectinemia was associated with impaired endothelium-dependent vasodilatation and reduced blood flow ${ }^{[37]}$ and was an independent risk factor for hypertension ${ }^{[36]}$. Analysis of mutations in the human adiponectin gene provides further information about the link between adiponectin and hypertension. Among several single-nucleotide polymorphisms of adiponectin gene, singlenucleotide polymorphism at position 164 has been associated with hypoadiponectinemia and high blood pressure ${ }^{[38]}$. Further, Tanida et al. ${ }^{[39]}$ reported that adiponectin dose-dependently decreases renal sympathetic nerve activity and blood pressure in rats and that its action may be mediated through the hypothalamic suprachiasmatic nucleus.

On the other side, the present study showed a significant negative correlation between serum adiponectin levels and HOMA-insulin resistance index (HOMA-IR) among preeclamptic women. Plasma adiponectin levels decreased in parallel with the progression of insulin resistance, suggesting that a reduction in circulating adiponectin may be related to the development of insulin resistance [40] and these findings may be coupled with Combs et al. ${ }^{[41]}$. who reported that administration of recombinant adiponectin can lead to enhance insulin action. 
Consequently, it appeared that this peptide could play a physiological role in maintaining insulin sensitivity and glucose homeostasis. This suggestion could not exclude the possibility that insulin may also have an effect to modulate adiponectin production from adipocytes [42], so giving adiponectin as a drug in high risk women before and during early pregnancy may reduce risk of preeclampsia by increasing insulin sensitivity.

Regarding correlation between maternal adiponectin levels and body mass index (BMI), the present study showed a significant negative correlation between maternal serum levels of adiponectin and body mass index among preeclamptic women. Hendeler et al. ${ }^{[43]}$ concluded that pregnant women complicated with severe preeclampsia and had body mass index greater than $25 \mathrm{~kg} / \mathrm{m} 2$ have decreased serum adiponectin

levels, while normal weight preeclamptic women have increased serum adiponectin levels. It was suggested that increased adiponectin levels in normal weight preeclamptic women may represent normal feedback response, but this mechanism might not function properly in overweight and obese preeclamptic woman because of increased adiponectin levels and insulin resistance, suggesting that decreased adiponectin level may play a role in pathophysiology of preeclampsia ${ }^{[43]}$. In a contrast to study results about correlation between adiponectin levels and BMI, Herse et al. ${ }^{[44]}$ reported that adiponectin levels did not correlate with BMI. This can be explained that BMI in pregnancy doesn't accurately reflect fat stores because maternal weight is influenced by weight of the fetus, placenta and amnions and by plasma volume ${ }^{[45]}$.

Briefly, in case of preeclampsia in the present study, it has been observed that there is a significant increase in body mass index and insulin resistance index, and a significant decrease in plasma adiponectin. The increase in body mass index may be due to an increase in body fat mass which may be involved in systemic metabolic and vascular alterations ${ }^{[16]}$ this is evidenced by the correlation analysis which exhibited a significant negative correlation between adiponectin and body mass index, adiponectin and each of systolic blood pressure and diastolic blood pressure as vascular parameters, and adiponectin and HOMA-IR as a metabolic parameter.

\section{Conclusions}

Preeclamptic women are more insulin resistant, which was reflected through increased HOMA-IR value.

Insulin resistance may be one of the casual pathways of preeclampsia.

Improving insulin sensitivity in high risk women before and during early pregnancy may reduce risk of preeclampsia.

Preeclamptic women in third trimester of pregnancy had low adiponectin levels than normal pregnant women.

Hypoadiponectinemia may be one of the possible etiologies of preeclampsia, so measuring of this adipokine may be useful for prognosis of preeclampsia.

Preeclamptic mothers had lower placental weight and decreased number of cotyledons per placenta with marginal insertion of umbilical cord compared with normal placentae

Preeclamptic placentae underwent definite morphological changes seemed to be the result of insufficiency of placenta in preeclampsia.

\section{References}

1 Sibai B, Dekker G, Kupferminc M. Preeclampsia. Lancet 2005; 365(9461): 785-799 [PMID: 15733721 DOI: 10.1016/S01406736(05)17987-2]

2 Grinspoon S. Abnormal glucose regulation and treatment strategies for insulin resistance HIV - infected patients. $\boldsymbol{A m} \boldsymbol{J}$ Infect Dis 2006; 2:184-6.

3 Wolf M, Sandler L, Munoz K, Hsu K, Ecker JL, Thadhani R. First trimester insulin resistance and subsequent preeclampsia: a prospective study. J Clin Endocrinol Metab 2002; 87(4): 1563-1568 [PMID: 11932283 DOI: $10.1210 /$ jcem.87.4.8405]

4 Chen MP, Chung FM, Chang DM, Tsai JC, Huang HF, Shin SJ, Lee YJ. Elevated plasma level of visfatin/pre-B cell colony-enhancing factor in patients with type 2 diabetes mellitus. J Clin Endocrinol Metab 2006; 91(1): 295 - 
299 [PMID: 16234302 DOI: $10.1210 /$ jc. $2005-$ 1475]

5 Wang Y, Lam KS, Xu JY, Lu G, Xu LY, Cooper GJ, Xu A. Adiponectin inhibits cell proliferation by interacting with several growth factors in an oligomerization-dependent manner. J Biol Chem 2005; 280(18): 1834118347 [PMID: 15734737 DOI: 10.1074/jbc.M501149200]

6 Lindsay RS, Funahashi T, Hanson RL, Matsuzawa Y, Tanaka S, Tataranni PA, Knowler WC, Krakoff J. Adiponectin and development of type 2 diabetes in the Pima Indian population. Lancet 2002; 360(9326): 57-58 [PMID: 12114044 DOI: 10.1016/S0140-6736(02)09335-2]

7 Ramsay JE, Jamieson N, Greer IA, Sattar N. Paradoxical elevation in adiponectin concentrations in women with preeclampsia. Hypertension 2003; 42(5): 891-894 [PMID: 14517227

DOI:

10.1161/01.HYP.0000095981.92542.F6]

8 Mori T, Shinohara K, Wakatsuki A, Watanabe $\mathrm{K}$, Fujimaki A. Adipocytokines and endothelial function in preeclamptic women. Hypertens Res 2010; 33(3): 250-254 [PMID: 20075929 DOI: 10.1038/hr.2009.222]

9 Lamb E, Newman DJ, Price CP. Kidney function tests. In: Buritis CA, Ashwood ER, Burn DE. Teitz textbook of clinical chemistry and molecular diagnostics. 4 th edition. $\boldsymbol{W B}$ Sauders, Philadelphia 2006, pp. 795-835

10 Bernard A, Lauwerys R. Latex immunoassay of urinary albumin. $\boldsymbol{J}$ Clin Chem Clin Biochem 1983; 21(1): 25-30 [PMID: 6854217]

11 Chavan VU, Sayyed AK, Durgawale PP, Sontakke AV, et al. Practical Aspects of Calculation, Expression and Interpretation of Urine Albumin Measurement. NJIRM 2011; 2(1):29-34.

12 Tietz NW. Clinical Guide to laboratory Tests. 3rd edition. WB Sauders Company, Philadelphia 1995, pp. 268-9.

13 Starr JI, Mako ME, Juhn D, Rubenstein AH. Measurement of serum proinsulin-like material: cross-reactivity of porcine and human proinsulin in the insulin radioimmunoassay. $\boldsymbol{J}$ Lab Clin Med 1978; 91(4): 683-692 [PMID: 641392]
14 Matthews DR, Hosker JP, Rudenski AS, Naylor BA, Treacher DF, Turner RC. Homeostasis model assessment: insulin resistance and beta-cell function from fasting plasma glucose and insulin concentrations in man. Diabetologia 1985; 28(7): 412-419 [PMID: 3899825]

15 Tsao TS, Lodish HF, Fruebis J. ACRP30, a new hormone controlling fat and glucose metabolism. Eur J Pharmacol 2002; 440(2-3): 213-221 [PMID: 12007537]

16 Zhang $\mathrm{H}$, Zhang C. Regulation of Microvascular Function by Adipose Tissue in Obesity and Type 2 Diabetes: Evidence of an Adipose-Vascular Loop. Am J Biomed Sci 2009; 1(2): 133 [PMID: 20098632 PMCID: PMC2809393]

17 Ryan EA, Enns L. Role of gestational hormones in the induction of insulin resistance. J Clin Endocrinol Metab 1988; 67(2): 341347 [PMID: 3292560 DOI: 10.1210/jcem-672-341]

18 Kameda T, Matsuzaki N, Sawai K, Okada T, Saji F, Matsuda T, Hirano T, Kishimoto T, Tanizawa O. Production of interleukin- 6 by normal human trophoblast. Placenta 1990; 11(3): 205-213 [PMID: 2371251]

19 Masuzaki H, Ogawa Y, Sagawa N, Hosoda K, Matsumoto $\mathrm{T}$, Mise $\mathrm{H}$, Nishimura $\mathrm{H}$, Yoshimasa Y, Tanaka I, Mori T, Nakao K. Nonadipose tissue production of leptin: leptin as a novel placenta-derived hormone in humans. Nat Med 1997; 3(9): 1029-1033 [PMID: 9288733]

20 Cobellis L, De Falco M, Mastrogiacomo A, Giraldi D, Dattilo D, Scaffa C, Colacurci N, De Luca A. Modulation of apelin and APJ receptor in normal and preeclampsiacomplicated placentas. Histol Histopathol 2007; 22(1): 1-8 [PMID: 17128405 DOI: 10.14670/HH-22.1]

21 Masuyama H, Inoue S, Hiramatsu Y. Retinolbinding protein 4 and insulin resistance in preeclampsia. Endocr $\boldsymbol{J}$ 2011; 58(1): 47-53 [PMID: 21173508]

22 Brosens JJ, Pijnenborg R, Brosens IA. Myometrial junction zone spiral arteries in normal and abnormal pregnancies: a review of 
the literature. Am J Obstet Gynecol 2002; 187:1416 - 23 .

23 Evans JL, Goldfine ID, Maddux BA, Grodsky GM. Are oxidative stress-activated signaling pathways mediators of insulin resistance and beta-cell dysfunction? Diabetes 2003; 52(1): 18 [PMID: 12502486]

24 Chandran M, Phillips SA, Ciaraldi T, Henry RR. Adiponectin: more than just another fat cell hormone? Diabetes Care 2003; 26(8): 2442-2450 [PMID: 12882876]

25 Chen J, Tan B, Karteris E, Zervou S, Digby J, Hillhouse EW, Vatish M, Randeva HS. Secretion of adiponectin by human placenta: differential modulation of adiponectin and its receptors by cytokines. Diabetologia 2006; 49(6): 1292-1302 [PMID: 16570162 DOI: 10.1007/s00125-006-0194-7]

26 Haugen F, Ranheim T, Harsem NK, Lips E, Staff AC, Drevon CA. Increased plasma levels of adipokines in preeclampsia: relationship to placenta and adipose tissue gene expression. Am J Physiol Endocrinol Metab 2006; 290(2): E326-333 [PMID: 16144822 DOI: 10.1152/ajpendo.00020.2005]

27 Khosrowbeygi A, Lorzadeh N, Ahmadvand H. Lipid peroxidation is not associated with adipocytokines in preeclamptic women. Iran $\boldsymbol{J}$ Reprod Med 2011; 9(2): 113-118 [PMID: 25587257 PMCID: PMC4216445]

28 Masuyama H, Segawa T, Sumida Y, Masumoto A, Inoue S, Akahori Y, Hiramatsu Y. Different profiles of circulating angiogenic factors and adipocytokines between early- and late-onset pre-eclampsia. BJOG 2010; 117(3): 314-320 [PMID: 20015306 DOI: 10.1111/j.1471-0528.2009.02453.x]

29 Naruse K, Yamasaki M, Umekage H, Sado T, Sakamoto Y, Morikawa H. Peripheral blood concentrations of adiponectin, an adipocytespecific plasma protein, in normal pregnancy and preeclampsia. J Reprod Immunol 2005; 65(1): 65-75 [PMID: 15694968 DOI: 10.1016/j.jri.2004.09.004]

30 D'Anna R, Baviera G, Corrado F, Giordano D, Di Benedetto A, Jasonni VM. Plasma adiponectin concentration in early pregnancy and subsequent risk of hypertensive disorders. Obstet Gynecol 2005; 106(2): 340-344 [PMID:
16055585

DOI:

10.1097/01.AOG.0000168441.79050.03]

31 Lu D, Yang X, Wu Y, Wang H, Huang H, Dong M. Serum adiponectin, leptin and soluble leptin receptor in pre-eclampsia. Int $\boldsymbol{J}$ Gynaecol Obstet 2006; 95(2): 121-126 [PMID: 16919629 DOI: $10.1016 /$ j.ijgo.2006.06.015]

32 Kishwara S, Ara S, Abu Rayhan K, Begum M. Morphological Changes of Placenta in Preeclampsia. Bangladesh Journal of Anatomy 2009; 7(1):49-54.

33 Majumdar S, Dasgupta H, Bhattacharya K, Bhattacharya A. A Study of Placenta in Normal and Hypertensive Pregnancies. J Anat Soc India 2005; 54 (2): 1-9.

34 Queenan JT, Hobbins JC. Management of high risk pregnancy. 4th edition. Blackwell science Inc, England 1999, pp 261-70.

35 Abd-Alaleem DI, Attiaa KI, Khalefa AA, Ahmad RA. Adiponectin levels in serum of women with preeclampsia. East Mediterr Health J 2011; 17(7): 575-581 [PMID: 21972480]

36 Ouchi N, Shibata R, Walsh K. Targeting adiponectin for cardioprotection. Expert Opin Ther Targets 2006; 10(4): 573-581 [PMID: 16848693 DOI: $\underline{10.1517 / 14728222.10 .4 .573}]$

37 Tan KC, Xu A, Chow WS, Lam MC, Ai VH, Tam SC, Lam KS. Hypoadiponectinemia is associated with impaired endotheliumdependent vasodilation. J Clin Endocrinol Metab 2004; 89(2): 765-769 [PMID: 14764794 DOI: 10.1210/jc.2003-031012]

38 Iwashima Y, Katsuya T, Ishikawa K, Ouchi N, Ohishi M, Sugimoto K, Fu Y, Motone M, Yamamoto K, Matsuo A, Ohashi K, Kihara S, Funahashi T, Rakugi H, Matsuzawa Y, Ogihara T. Hypoadiponectinemia is an independent risk factor for hypertension. Hypertension 2004; 43(6): 1318-1323 [PMID: 15123570 DOI: 10.1161/01.HYP.0000129281.03801.4b]

39 Tanida M, Shen J, Horii Y, Matsuda M, Kihara S, Funahashi T, Shimomura I, Sawai H, Fukuda Y, Matsuzawa Y, Nagai K. Effects of adiponectin on the renal sympathetic nerve activity and blood pressure in rats. Exp Biol Med (Maywood) 2007; 232(3): 390-397 [PMID: 17327472] 
40 Haluzik M, Parizkova J, Haluzik MM. Adiponectin and its role in the obesity-induced insulin resistance and related complications. Physiol Res 2004; 53(2): 123-129 [PMID: 15046547]

41 Combs, TP, Wagner JA, Berger J, Doebber T, Wang WJ, Zhang BB, et al. Induction of adipocyte complement-related protein of 30 kilo Daltons by PPAR- a agonists: a potential mechanism of insulin sensitization. Endocrinology 2002; 143(3):998-1007.

$42 \mathrm{Yu} \mathrm{JG}$, Javorschi S, Hevener AL, et al. The effect of thiazolidinediones on plasma adiponectin level in normal, obese, and type-2diabetic subjects. Diabetes 2002; 51(10):296874.
43 Hendler I, Blackwell SC, Mehta SH, Whitty JE, Russell E, Sorokin Y, Cotton DB. The levels of leptin, adiponectin, and resistin in normal weight, overweight, and obese pregnant women with and without preeclampsia. $\boldsymbol{A m} \boldsymbol{J}$ Obstet Gynecol 2005; 193(3 Pt 2): 979-983 [PMID: 16157097

DOI: 10.1016/j.ajog.2005.06.041]

44 Herse F, Bai Y, Staff AC, Yong-Meid J, Dechend R, Zhou R. Circulating and uteroplacental adipocytokine concentrations in preeclampsia. Reprod Sci 2009; 16(6): 584590 [PMID: 19276406

DOI: 10.1177/1933719109332828]

45 Ozkan S, Erel CT, Madazli R, Aydinli K. Serum leptin levels in hypertensive disorder of pregnancy. Eur J Obstet Gynecol Reprod Biol 2005; 120(2): 158-163 [PMID: 15925044 DOI: $\underline{10.1016 / \text { j.ejogrb.2004.02.046] }}$ 